\title{
The community structure of macroscopic basidiomycetes (Fungi) in Brazilian mangroves influenced by temporal and spatial variations
}

\author{
Georgea Santos Nogueira-Melo ${ }^{1}$, Paulo Jorge Parreira Santos ${ }^{2} \&$ Tatiana Baptista Gibertoni ${ }^{1}$ \\ 1. Departamento de Micologia, Universidade Federal de Pernambuco, Av. Nelson Chaves s/n, CEP 50760-420, Recife, \\ PE,Brazil; geomycota@gmail.com, tatiana.gibertoni@pq.cnpq.br \\ 2. Departamento de Zoologia, Universidade Federal de Pernambuco, Av. Nelson Chaves s/n, CEP 50760-420, Recife, \\ PE, Brazil; pjp.santos@gmail.com
}

Received 12-XII-2013. C Corrected 22-V-2014. Accepted 24-VI-2014.

\begin{abstract}
Mangroves are transitional ecosystems between terrestrial and marine environments, and are distinguished by a high abundance of animals, plants, and fungi. Although macrofungi occur in different types of habitat, including mangroves, little is known about their community structure and dynamic. Therefore the aim of this study was to analyze the diversity of macrofungi in a number of Brazilian mangroves, and the relationship between such diversity, precipitation and area of collection. A total of 32 field trips were undertaken from 2009 to 2010, and macrofungi were studied in four $250 \times 40 \mathrm{~m}$ transects: Timbó and Santa Cruz Channel on the Northern coast, and Maracaípe and Ariquindá on the Southern coast. All basidiomata found along the transects were placed in paper bags, air-dried and identified using existing literature. It was found that Northern areas predominantly featured Avicennia schaueriana mangroves, while Rhizophora mangle dominated in Southern transects. A total of 275 specimens were collected, and 33 species, 28 genera, 14 families and six orders were represented. Overall abundance and species richness did not vary significantly among areas, but varied according to time, being higher during the rainy season. Subtle differences in composition were observed over time and between areas, probably due to variations in plant species occurrence. Further studies with collections during months of greater precipitation in transects dominated by different mangrove species of the same ecosystem are suggested to assess the overall diversity of mycobiota in these ecosystems. Rev. Biol. Trop. 62 (4): 1587-1595. Epub 2014 December 01.
\end{abstract}

Key words: Agaricomycetes, diversity, ecological interactions, estuaries, fungi.

Mangroves are transitional ecosystems between terrestrial and marine environments and are important for the maintenance of biodiversity and water quality, sediment fixing, and the supply of primary production to the surroundings (Cintrón \& Schaeffer-Novelli, 1980). Mangroves are known for their particular vegetation and, while not being speciesrich, are distinguished by a high abundance of animals, plants, and fungi (Silva, Bernini \& Carmo, 2005).

Macrofungi occur in different habitat types, including mangroves, and are found with higher frequency and diversity in tropical forests. Due to their saprotrophic, parasitic, or symbiotic lifestyles, they play an essential role in the ecological balance of forest areas. Macroscopic basidiomycetes (a type of fungi known as mushrooms, bracket fungi, earthstars, among others) can be found on living or dead wood, in soil, in mycorrhizal or lichen associations, or as plant parasites (Alexopoulos, Mims \& Blackwell, 1996; Kendrick, 2000; Deacon, 2006; Webster \& Weber, 2007).

Despite the importance of decaying wood fungi, little is known about their community structure and dynamic in mangroves. Information of the distribution patterns and the factors that control or limit their diversity in such environments in tropical areas is scarce (Lindblad, 
2000; Lindblad, 2001; Gilbert \& Sousa, 2002; Urcelay \& Robledo, 2004; Robledo, Urcelay, Domínguez \& Rajchenberg, 2006; Gibertoni, Santos \& Cavalcanti, 2007; Gibertoni, 2008; Gilbert, Gorospe \& Ryvarden, 2008; DrechslerSantos, Santos, Gibertoni \& Cavalcanti, 2010; Robledo \& Renison, 2010; Trierveiler-Pereira, Santos \& Baseia, 2013). Of these, only two studies were undertaken in mangroves. Gilbert \& Sousa (2002) observed that macrofungi occur more frequently in a particular type of substrate, while Gilbert et al. (2008) observed the host and habitat preferences of polypores in three well-defined, floristically distinct, tropical wetlands, which included mangroves. In the latter case, the habitat preference was related to specificity for a particular host. In Brazil only species checklists and descriptions are available (Sotão, Bononi, \& Figueiredo, 1991; Almeida-Filho, Bueno \& Bononi, 1993; Gugliotta \& Capelari, 1995; Campos \& Cavalcanti, 2000; Campos, Sotão, Cavalcanti \& Luz, 2005; Baltazar, Trierveiler-Pereira \& Loguercio-Leite, 2009; Nogueira-Melo, Ryvarden \& Gibertoni, 2011; Nogueira-Melo et al., 2012)

The aim of the present study was to determine the structure and describe the specific composition of a wood-decaying fungi community through the occurrence of basidiomata in four different mangroves areas in Brazil. Spatial variations between areas and temporal variations between the two main seasons of the year were also described. The data was used to test the hypothesis that diversity of fungi is directly affected by both rainfall and area of collection.

\section{MATERIALS AND METHODS}

The study was conducted in four mangrove areas, belonging to four estuaries in the state of Pernambuco in the Northeast of Brazil. Two were along the Northern coast: mangrove from the Timbó river (T) $\left(07^{\circ} 51^{\prime} 24^{\prime \prime}{ }^{\prime \prime}\right.$ $\left.\mathrm{S}-34^{\circ} 50^{\prime} 32^{\prime \prime} 7^{\prime} " \mathrm{~W}\right)$ and mangrove from the Santa Cruz Chanel (S) (07046'52"6" S 34 52'53"3" W), where Avicennia schaueriana predominates; and two along the Southern coast: mangrove from the Maracaípe river (M) (08'32'22" $"$ " S - 35 00'29" 1 " W) and mangrove from the Ariquindá river (A) (08\%41'20" 8 " S - 3506'6"6" W), where Rhizophora mangle predominates. Northern coast mangroves were surrounded by urban areas, while those from the Southern coast were distant from such areas (Montes, Macêdo \& Koening, 2002; Mendonça \& Almeida-Cortez, 2007). The Northern mangroves are approximately $45 \mathrm{~km}$ apart, while those from the Southern coast are $40 \mathrm{~km}$ apart. The Northern and Southern mangroves are around $100 \mathrm{~km}$ apart.

Three typical mangrove tree species were frequently found in the study areas: Avicennia schaueriana Stapf. and Leech (black mangrove), Laguncularia racemosa (L.) Gaertn (white mangrove), and Rhizophora mangle L. (red mangrove). In the studied forests, these species are differentially distributed according to distance from the water's edge, but their distributions overlap to varying degrees (Cintrón \& Schaeffer-Novelli, 1980; Schaeffer-Novelli, Cintrón-Molero, Andaime \& Camargo, 1990).

The climate in these areas is defined as tropical humid (Am by Köepen classification), with high monthly and low annual temperature amplitude, an average annual temperature of $21^{\circ} \mathrm{C}$ and annual precipitation greater than 1 $500 \mathrm{~mm}$ (Peel, Finlayson \& McMahon, 2007).

In order to study fungi in these areas, one transect of $250 \times 40 \mathrm{~m}\left(10000 \mathrm{~m}^{2} ; 20 \mathrm{~m}\right.$ to the right and $20 \mathrm{~m}$ to the left of the transect), starting in the estuary and roughly following a line parallel to the water channel, was established in each mangrove, using Global Position System (GPS). A collection trip was undertaken monthly in each of the four areas for eight months (Apr, May, Jun, Jul, Aug, Sep, 2009; Jan and Mar 2010), totaling 32 field trips (16 along each coast).

All basidiomata found along transects were placed in paper bags and collection data (position, date and substrate) was recorded. The material was air-dried and identified with help of existing literature (Ryvarden \& Johansen, 1980; Gilbertson \& Ryvarden, 1986; 1987; Hjortstam, Larsson \& Ryvarden, 1987; 1988; 
Ryvarden, 1991; Boidin, Lanquetin \& Gilles, 1997; Boidin \& Gilles, 2000; Núñez \& Ryvarden, 2000; 2001; Ryvarden, 2004; Bernicchia, 2005). Nomenclature from the CABI online database (www.indexfungorum.org) was used. Identified material in good condition was incorporated into the URM Herbarium, of the Department of Mycology of the Universidade Federal de Pernambuco, and duplicates were sent to the O Herbarium of the University of Oslo. Samples of the same species collected in the same area in the same substrate and on the same date were identified as one combined voucher specimen.

Species abundance values were represented by the number of occurrences of specimens/individuals in each substrate per transect (ind. $/ 10000 \mathrm{~m}^{2}$ ). One specimen/individual may be represented by several basidiomata.

Statistical analysis was performed in accordance with the methods proposed by Clarke \& Warwick (1994) using the PRIMER ${ }^{\circledR}$ 6 (Plymouth Routines in Multivariate Ecological Research) software.

Two-way variance analysis (ANOVA) was used to determine significant differences for abundance and richness between both mangroves and precipitation periods (dry and wet), and two-way similarity analysis (ANOSIM) was used to determine significant differences in the macrofungi community structure between the four mangroves and sampling seasons. Bartlett's test was used to determine the homogeneity of variances and values were transformed into Neperian logarithms if necessary.

The Bray-Curtis index was applied to standardized data to assess the similarity between replicates. Multi-dimensional scaling (MDS) was used to represent the similarity matrix.

The BioEstat 5.0 method of binomial probability distribution was used to evaluate spatial distribution and verify if there was predominance of some fungal species in any of the mangroves. Species considered not to be rare were used in the analysis and the areas were tested separately. In the present study, rare species were those whose frequency of occurrence was $0.5<\mathrm{F} \leq 1.5 \%$, using the formula:
$\mathrm{F}=\mathrm{n} \times 100 / \mathrm{N}$, where $\mathrm{n}=$ number of specimens from one species and $\mathrm{N}=$ total number of specimens (Lindblad, 2000; Schnittler \& Stephenson, 2000). The probability value used (P) was that of species with higher incidence (Ayres, Ayres, Ayres \& Santos, 2007).

The normal approximation to the binomial test was used to verify the differences among plant proportions in areas using BioEstat 5.0 software. Since six paired comparisons were made, the significance level was set at $\mathrm{p}<0.01$ for this analysis. If not stated, the level of significance was set at $\mathrm{p}<0.05$ for all other analyses.

Abiotic factors considered in this study were temperature and rainfall, data of which was provided by the Instituto de Tecnologia de Pernambuco - ITEP/Agência Pernambucana de Água e Clima (APAC). Dry months (Sep 2009, Jan and Mar 2010) were considered those in which the total value of precipitation was below the lower limit of the confidence interval (95\%) for the average annual monthly precipitation over the last 10 years.

\section{RESULTS}

A total of 275 specimens were analyzed, representing 33 species, 28 genera, 14 families and six orders. Of the 14 families, four presented more than 15 records and together constituted $70 \%$ of specimens collected: Gloeophyllaceae, with 55 records, was represented only by Gloeophyllum striatum; Hymenochaetaceae, which had 25 occurrences of two genera and four species; Polyporaceae, which had 95 occurrences corresponding to nine species and eight genera; and Schizoporaceae, which had 26 records and was represented exclusively by Schizopora paradoxa (Table 1).

From the 275 collected specimens, 81 occurred in S, 66 in T, 73 in M and 55 in A. The Santa Cruz Chanel presented the highest number of genera and species (18 and 20, respectively), followed by $\mathrm{T}$ (15 genera, 16 species), M $(12,16)$ and $\mathrm{A}(12,13)$. Although richness and abundance varied, they did not differ significantly between areas $\left[\mathrm{F}_{(3 ; 21)}=3.324\right.$, 
TABLE1

Wood decaying fungi collected in four Brazilian mangroves (A=Ariquindá; M=Maracaípe; $\mathrm{S}=$ Santa Cruz Chanel; $\mathrm{T}=$ Timbó) and occurrence by substrate (As=Avicennia schaueriana; Lr=Laguncularia racemosa; Rm=Rhizophora mangle)

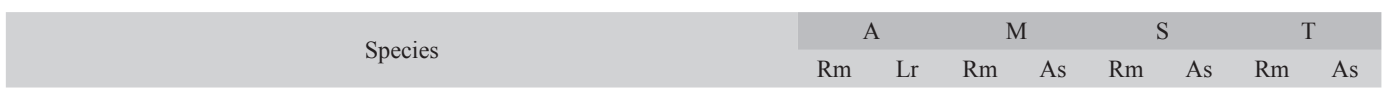

CORTICIACEAE Herter

Punctularia strigosozonata (Scheinw.) P.H.B. Talbot

DACRYMYCETACEAE J. Schröt.

Cerinomyces aculeatus N. Maekawa

FOMITOPSIDACEAE Jülich

Fomitopsis nivosa (Berk.) Gilb. \& Ryvarden

GLOEOPHYLLACEAE Jülich

Gloeophyllum striatum (Sw.) Murrill

HYMENOCHAETACEAE Donk

Fuscoporia contigua (Pers.) G. Cunn.

Phellinus cf. rhytiphloeus (Mont.) Ryvarden

Phellinus gilvus (Schwein.) Pat.

Phellinus mangrovicus (Imazeki) Imazeki

Phellinus rimosus (Berk.) Pilát

LACHNOCLADIACEAE D.A. Reid

Asterostroma cervicolor (Berk. \& M.A. Curtis) Massee

MERULIACEAE Rea

Cerocorticium molle (Berk. \& M.A. Curtis) Jülich

Gloeoporus dichrous (Fr.) Bres.

Hyphoderma iguazuense Hjortstam \& Ryvarden

Hyphoderma $\mathrm{sp}$.

PENIOPHORACEAE Lotsy

Gloeocystidiopsis cf. salmonea (Burt) Boidin, Lanq. \& Gilles

$\mathrm{x}$

HANEROCHAETACEAE Jülich

Ceriporia spissa (Schwein. ex Fr.) Rajchenb.

Phanerochaete australis Jülich

Phlebiopsis ravenelii (Cooke) Hjortstam

POLYPORACEAE Fr. ex Corda

Coriolopsis hostmanii (Berk.) Ryvarden

Hexagonia hydnoides (Sw.) M. Fidalgo

Hjortstamia amethystea (Hjortstam \& Ryvarden) Boidin \& Gilles

Lentinus bertieri (Fr.) Fr.

Lopharia $\mathrm{sp.}$

Loweporus tephroporus (Mont.) Ryvarden

Perenniporia detrita (Berk.) Ryvarden

Perenniporia guyanensis Decock \& Ryvarden

Pycnoporus sanguineus (L.) Murrill

Trichaptum biforme (Fr.) Ryvarden

SCHIZOPHYLLACEAE Quél.

Schizophyllum commune Fr.

SCHIZOPORACEAE Jülich

Schizopora paradoxa (Schrad.) Donk

STEREACEAE Pilát

Gloeocystidiellum triste Hjortstam \& Ryvarden

Gleodontia discolor (Berk. \& M.A. Curtis) Boidin

TRICHOLOMATACEAE R. Heim ex Pouzar

Resupinatus poriaeformis (Pers.) Thorn, Moncalvo \& Redhead 


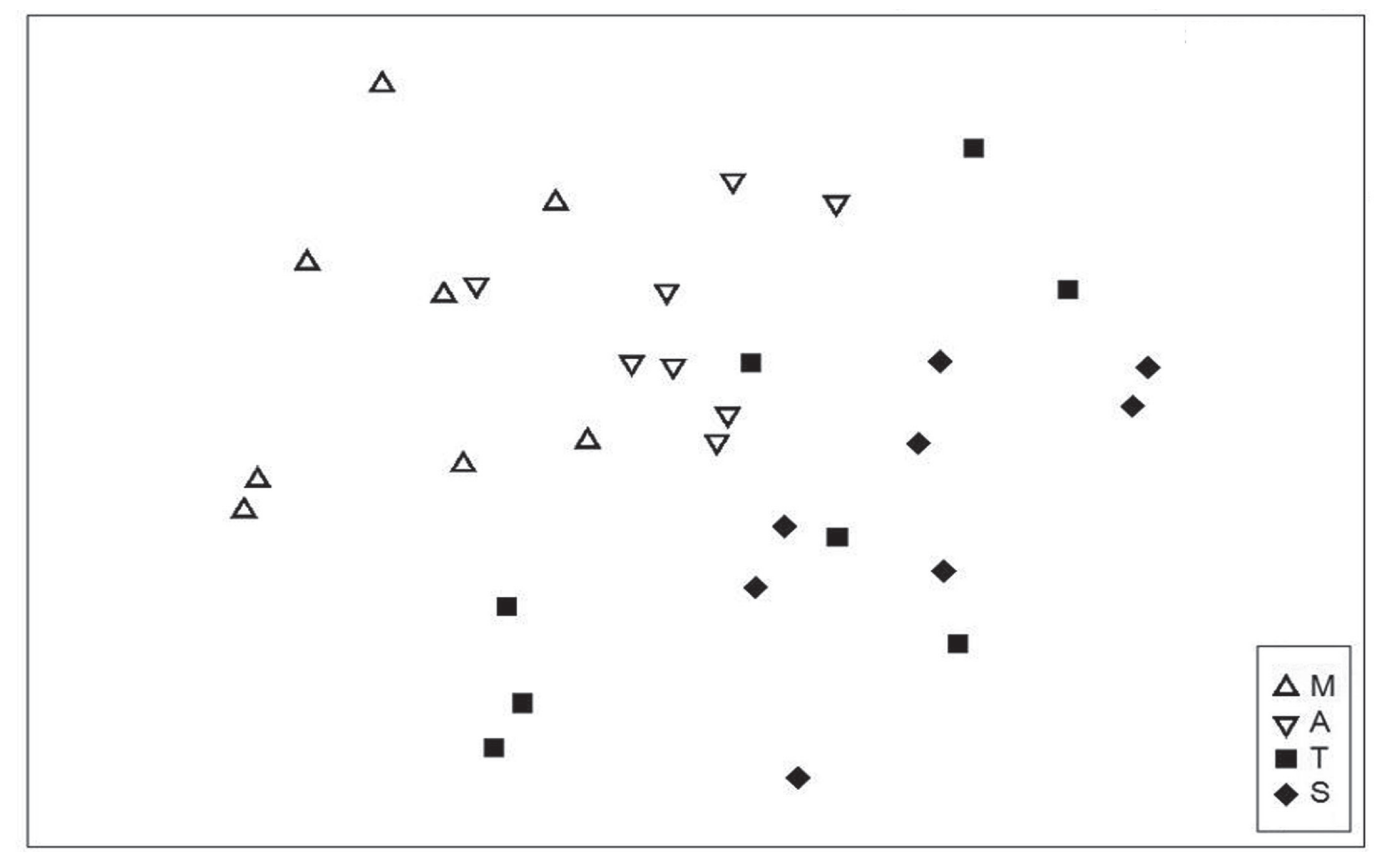

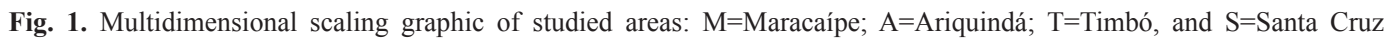
Chanel. Resemblance: S17 Bray Curtis similarity. 2D Stress: 0:19.

$\mathrm{p}=0.015 ; \mathrm{F}_{(3 ; 21)}=1.060, \mathrm{p}=0.388$, respectively]. ANOSIM revealed subtle differences in the proportion of species of the fungal community among the four mangrove areas $\left(\mathrm{R}_{\mathrm{global}=0.384}\right.$, number of permutations $=999, \mathrm{p}=0.001)$, and between the northern ( $\mathrm{S}$ and $\mathrm{T}$ ) and southern mangroves (A and $\mathrm{M})\left(\mathrm{R}_{\text {global }=0.33}\right.$, number of permutations $=999, \mathrm{p}=0.001$ ) (Fig. 1).

Of the 33 species, four were common to all four areas: G. striatum, P. gilvus, S. paradoxa and $T$. biforme. Significantly different rates of occurrence according to area were found for nine of the 11 fungal species $(82 \%)$ which were sufficiently abundant for statistical testing (Table 2, in bold). Coriolopsis hostmanii, P. gilvus and T. biforme were predominant in $\mathrm{S}$; $H$. hydnoides and H. iguazuense in T; P. guyanensis and $G$. striatum in $\mathrm{M}$, and $S$. paradoxa in A, while the values of $H$. amethystea and $P$. detrita were not different from random occurrence levels (Table 2).

The studied areas differed in proportions of mangrove species. Northern coastal transects showed predominance of A. schaueri$a n a$, while Southern coastal transects presented mostly $R$. mangle $(\mathrm{M} \times \mathrm{A}: \mathrm{Z}=1.043, \mathrm{p}=0.297$; $\mathrm{M} \times \mathrm{S}: \mathrm{Z}=7.677, \quad \mathrm{p}<0.0001 ; \quad \mathrm{M} \times \mathrm{T}: \mathrm{Z}=9.065$, $\mathrm{p}<0.0001 ; \quad \mathrm{A} \times \mathrm{S}: \mathrm{Z}=6.680 \quad \mathrm{p}<0.0001 ;$ $\mathrm{A} \times \mathrm{T}: \mathrm{Z}=8.072, \quad \mathrm{p}<0.0001 ; \quad \mathrm{S} \times \mathrm{T}: \quad \mathrm{Z}=2.220$, $\mathrm{p}=0.0264$ ).

Average rainfall in the four areas from April 2009 to March 2010 was $174.13 \mathrm{~mm}$, varying monthly from $0 \mathrm{~mm}$ to $543.2 \mathrm{~mm}$. The mean temperature was $25.17^{\circ} \mathrm{C}$. The driest month was October $(11.6 \mathrm{~mm})$ and the wettest month was April (409.85mm). January, February, March, September, October, November and December were considered to be the dry season, while April, May, June, July and August represented the rainy season (Fig. 2).

Of the 275 collected specimens, $30(=15$ species) were found in April, 41 (=17) in May, $53(=20)$ in June, $40(=14)$ in July, $31(=16)$ in August, $35(=16)$ in September, $32(=11)$ in December and 13 (=six) in March. There was a significant difference in sample richness 
TABLE 2

Wood decaying fungi collected in four Brazilian mangroves of sufficient abundance for analysis of predominance by area ( $\mathrm{S}=$ Santa Cruz Chanel; M=Maracaípe; T=Timbó and $\mathrm{A}=$ Ariquindá)

\begin{tabular}{lccccc}
\multicolumn{1}{c}{ Species } & S & T & M & A & p \\
Trichaptum biforme (Fr.) Ryvarden & $\mathbf{2 5}$ & 7 & 1 & 8 & 0.0001 \\
Coriolopsis hostmannii (Berk.) Ryvarden & $\mathbf{1 0}$ & 1 & 0 & 0 & 0.001 \\
Phellinus gilvus (Schwein.) Pat. & $\mathbf{9}$ & 5 & 1 & 2 & 0.0028 \\
Hexagonia hydnoides (Sw.) M. Fidalgo & 4 & $\mathbf{9}$ & 0 & 0 & 0.0018 \\
Cerocorticium molle (Berk. \& M.A. Curtis) Jüllich & 0 & $\mathbf{8}$ & 1 & 3 & 0.0039 \\
Hyphoderma iguazuense Hjortstam \& Ryvarden & 0 & $\mathbf{8}$ & 0 & 2 & 0.0014 \\
Gloeophyllum striatum (Sw.) Murrill & 5 & 11 & $\mathbf{3 2}$ & 17 & 0.0029 \\
Perenniporia guyanensis Decock \& Ryvarden & 0 & 0 & $\mathbf{9}$ & 0 & 0.0018 \\
Schizopora paradoxa (Schrad.) Donk & 5 & 5 & 4 & $\mathbf{1 2}$ & 0.0076 \\
Perenniporia detrita (Berk.) Ryvarden & 1 & 0 & 6 & 3 & 0.0592 \\
Lopharia amethystea (Hjortstam \& Ryvarden) A.L.Weden & 3 & 2 & 2 & 1 & 0.1478 \\
Number of trees & 77 & 82 & 117 & 92 & \\
\hline
\end{tabular}
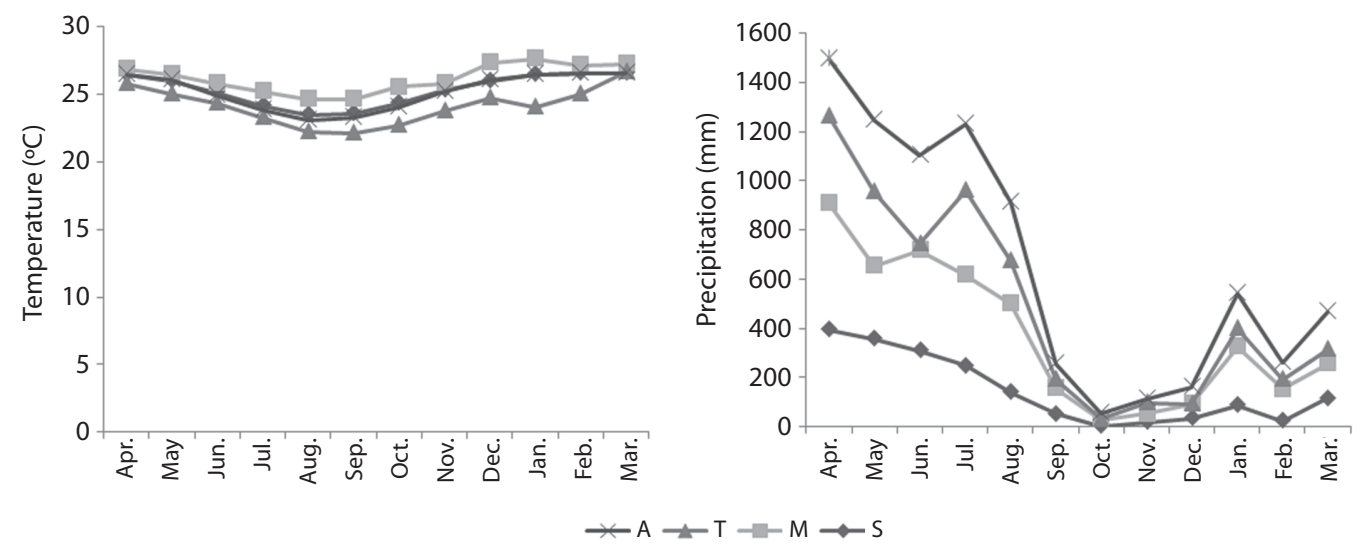

Fig. 2. Temperature and precipitation in the studied areas from April 2009 to March 2010. M=Maracaípe; A=Ariquindá; $\mathrm{T}=$ Timbó, and $\mathrm{S}=$ Santa Cruz Chanel.

according to time between June and March $\left[\mathrm{F}_{(3 ; 21)}=3.324, \mathrm{p}=0.015\right]$. Additionally, there were temporal differences in abundance among the collection periods: May, June, July and September yielded more specimens than March $\left[\left(\mathrm{F}_{(3 ; 21)}=4.055, \mathrm{p}=0.006\right)\right]$. A slight difference in species composition was also observed $\left(R_{\text {global }}=0.141\right.$, number of permutations $=999$, $\mathrm{p}=0.044)$ when occurrence of fungi in the dry and rainy season were compared.

\section{DISCUSSION}

The present study showed that the relative proportion of macroscopic basidiomycete species was different among the four studied areas, and between the Northern and Southern mangroves. Although the ANOSIM R $\mathrm{R}_{\text {global }}$ value found a statistical significant distinction among areas $\left(\mathrm{R}_{\text {global }} 0.384\right.$ and 0.33 , respectively), according to Clarke \& Warwick (1994), genuinely different communities would result in $\mathrm{R}_{\text {global }}$ values above 0.5 .

Therefore, the collected species belong to the same community (macrofungi inhabiting mangroves). However, the differential occurrence of about one-third of the 33 collected fungal species in the areas may have contributed to the observed distinction, although subtle, between areas. 
Furthermore, in transects of the Northern mangroves, A. schaueriana was predominant, while $R$. mangle was predominant in transects of the Southern mangroves. In estuaries, salinity and/or proximity to the sea influenced the distribution of mangrove plant species (Cintrón \& Schaeffer-Novelli, 1980; Schaeffer-Novelli et al., 1990). Additionally, the Northern mangroves were surrounded by urban areas, while the Southern mangroves were distant from such areas (Montes et al., 2002; Mendonça \& Almeida-Cortez, 2007), and thus have less antropic impacts. Hyde (1989) described the negative effects of hydrocarbon spillage on microfungi diversity in mangroves in Brunei, while Yamashita et al. (2008) described the negative effects of agriculture and isolated patches of natural forest on aphyllophoraceous diversity in Malaysia. However, the hypothesis that anthropization influences fungal communities was not tested in the present work. Hence, the distribution of the fungal species may reflect the vegetation in the studied transects.

In the present study, the abundance and richness of wood-decaying basidiomycetes (and to a lesser degree composition) were affected by precipitation: more specimens were collected in the rainy season and fewer during the dry season. The influence of precipitation on the occurrence of these macrofungi has also been reported in other ecosystems in Brazil. Gibertoni et al. (2007) observed that the former aphyllophoroid fungi were more frequently collected in the dry season, after peaks of rainfall in the Atlantic Forest. In Amazonia, Gibertoni (2008) found that the composition of polyporoid fungi species was different in the rainy than in the dry season. This indicates that rainfall is a factor that influences the occurrence of species and specimens.

However, Drechsler-Santos et al. (2010) observed in caatinga (semi-arid region), that rainfall did not influence the occurrence of species of Hymenochaetaceae, mostly found in living hosts. This is probably because they do not depend on environmental humidity as they are adapted to moisture hosts, according to Boddy \& Rayner (1983).
Recently, Trierveiler-Pereira et al. (2013) reported no significant differences in composition and species richness of epigeous Gasteromycetes according to collecting seasons in the Atlantic Forest, probably due to ephemeral basidiomata, which may not be observed, even during the rainy season.

The results of the present study support the tested hypothesis that diversity of macrofungi occurring in mangroves is directly affected by both rainfall and area of collection. We recommend further studies should collect samples during the higher precipitation months and from transects dominated by different mangrove plants in the same area in order to identify the overall diversity of the mycobiota in this ecosystem.

\section{ACKNOWLEDGMENTS}

The authors would like to thank their laboratory colleagues for support during the field trips; Leif Ryvarden and Karl-Henrik Larsson for species identification, Robert Lücking and Michael Finnie for English improvement and valuable suggestions, Roger Melo and Lucas Cavalcanti for help with figures. This research was supported by the Conselho Nacional de Desenvolvimento Científico e Tecnológico (CNPq, master scholarship of GSNM) and by FACEPE (APQ 0444-2.03/08).

\section{RESUMEN}

La estructura de la comunidad de basidiomicetos macroscópicos (Fungi) en los manglares brasileños influenciada por las variaciones temporales y espaciales. Los manglares son ecosistemas de transición entre los ambientes terrestres y marinos, y se distinguen por la gran abundancia de animales, plantas y hongos. Aunque los macrohongos se encuentran en diferentes tipos de hábitat, incluidos los manglares, poco se sabe acerca de la estructura de su comunidad y dinámica. Por lo tanto, el objetivo de este estudio fue analizar la diversidad de macrohongos en los manglares de Brasil y su relación con la precipitación y área de recolección. Se realizaron un total de 32 salidas de campo entre 2009 y 2010 , y los macrohongos fueron estudiados en cuatro transectos de $250 \times 40 \mathrm{~m}$ : Timbó y Canal de Santa Cruz en la costa norte y Maracaípe y Ariquindá en la costa sur. Todos los basidiomas encontrados 
a lo largo de los transectos se colocaron deshidratados en bolsas de papel, y se identificaron con ayuda de la literatura preexistente. Se encontró que las zonas del norte predominantemente presentaron Avicennia schaueriana, mientras Rhizophora mangle domina en transectos del sur. Se recolectaron un total de 275 especímenes y 33 especies, 28 géneros, 14 familias y seis órdenes estuvieron representados. Abundancia y riqueza de especies en general no varió significativamente entre las áreas, pero si varió en el tiempo, siendo mayor durante la estación lluviosa. Se observaron diferencias sutiles en la composición a través del tiempo y entre áreas, probablemente debido a las variaciones en la presencia de las especies de plantas. Otros estudios con recolectas durante los meses de mayor precipitación en transectos dominados por diferentes plantas de manglar en el mismo ecosistema son deseables para acceder a la diversidad de la micobiota.

Palabras clave: Agaricomycetes, diversidad, interacciones ecológicas, estuarios, hongos.

\section{REFERENCES}

Alexopoulos, C. J., Mims, C. W., \& Blackwell, M. (1996). Introductory Mycology (4 ${ }^{\text {th }}$ ed.). New York: John Wiley and Sons Press.

Almeida-Filho, O. M., Bueno, R., \& Bononi, V. L. R. (1993). Algumas espécies de fungos basidiomicetos dos manguezais do Estado de São Paulo. Hoehnea, 20(1/2), 87-92.

Ayres, M., Ayres, J. R. M., Ayres, D. L., \& Santos, A. A. S. (2007). BioEstat: Aplicações estatísticas nas áreas de ciências biomédicas ( $5^{\text {th }}$ ed.). Belém: Guanabara.

Baltazar, J. M., Trierveiler-Pereira, L., \& Loguercio-Leite, C. (2009). A. checklist of xylophilous basidiomycetes (Basidiomycota) in mangroves. Mycotaxon, 107, 221-224.

Bernicchia, A. (2005). Polyporaceae s.l. Fungi europaei 10. Alassio: Candusso.

Boddy, L. \& Rayner, A. D. M. (1983). Origins of decay in living deciduous trees: the role of moisture content and a re-appraisal of the expanded concept of tree decay. New Phytology, 94, 623-641.

Boidin, J., Lanquetin, P., \& Gilles, G. (1997). Le genre Gleocystidiellum sensu latu (Basidiomycotina). Bulletin trimestriel de la Société mycologique de France, 113.

Boidin, J. \& Gilles, G. (2000). Basidiomycètes Aphyllophorales de l'île de la Réunion XXI-suite. Mycotaxon, 75, 357-387.

Campos, E. L. \& Cavalcanti, M. A. Q. (2000). Primeira ocorrência de Phellinus mangrovicus (Imaz.) Imaz. para o Brasil. Acta botanica Brasilica, 14(3), 263-265.
Campos, E. L., Sotão, H. M. P., Cavalcanti, M. A. Q., \& Luz, A. B. (2005). Basidiomycetes de manguezais da APA de Algodoal-Maiandeua, Pará, Brasil. Boletim do Museu Paraense. Emílio Goeldi, 1(1), 97-102.

Cintrón, G. \& Schaeffer-Novelly, Y. (1980). Introducción a la ecologia del manglar. São Paulo: Instituto Oceanográfico USP.

Clarke, K. R. \& Warwick, R. M. (1994). Change in marine communities: an approach to statistical analysis and interpretation. Plymouth: Plymouth Marine Laboratory.

Deacon, J. W. (2006). Fungal biology (4 ${ }^{\text {th }}$ ed.). Massachusetts: Blackwell Publishing.

Drechsler-Santos, E. R., Santos, P. J. P., Gibertoni, T. B., \& Cavalcanti, M. A. Q. (2010). Ecological aspects of Hymenochaetaceae in an area of Caatinga (semi-arid) in Northeast Brazil. Fungal Diversity, 42, 71-78.

Gibertoni, T. B., Santos, P. J. P., \& Cavalcanti, M. A. Q. (2007). Ecological aspects of Aphyllophorales in the Atlantic Rain Forest in Northeast Brazil. Fungal Diversity, 25, 49-67.

Gibertoni, T. B. (2008). Polyporoid fungi (Agaricomycetes, Basidiomycota) in the Estação Científica Ferreira Penna (State of Pará, Brazilian Amazonia): diversity and ecological aspects. Scientifica Acta, 2, 70-74.

Gilbert, G. S. \& Sousa, W. P. (2002). Host specialization among wood-decay polypore fungi in a Caribbean mangrove forest. Biotropica, 34(3), 396-404.

Gilbert, G. S., Gorospe, J., \& Ryvarden, L. (2008). Host and habitat preferences of polypore fungi in Micronesian tropical flooded forests. Mycological Research, $112(6), 674-680$.

Gilbertson, R. L. \& Ryvarden, L. (1986). North American Polypores. (Vol. 1). Oslo: Fungiflora.

Gilbertson, R. L. \& Ryvarden, L. (1987). North American Polypores. (Vol. 1). Oslo: Fungiflora.

Gugliotta, A. M. \& Capelari, M. (1995). Polyporaceae from Ilha do Cardoso, SP, Brazil. Mycotaxon, 56, 107-113.

Hjortstam, K., Larsson, K. H., \& Ryvarden, L. (1987). The Corticiaceae of North Europe. (Vol. 1). Oslo: Fungiflora.

Hjortstam, K., Larsson, K. H., \& Ryvarden, L. (1988). The Corticiaceae of North Europe (Vol. 2). Oslo: Fungiflora.

Hyde, K. D. (1989). Ecology of tropical marine fungi. Hydrobiologia, 178, 199-208.

Kendrick, B. (2000). The fifth kingdom ( $2^{\text {nd }}$ ed.). Newburyport: Focus Information Group.

Lindblad, I. (2000). Host specificity of some wood-inhabiting fungi in a tropical forest. Mycologia, 92(3), 399-405. 
Lindblad, I. (2001). Diversity of poroid and some corticoid wood-inhabiting fungi along the rainfall gradient in tropical forests, Costa Rica. Journal of Tropical Ecology, 17, 353-369.

Mendonça, I. V. S. \& Almeida-Cortez, J. S. (2007). Caracterização da galha induzida por ácaro em Laguncularia racemosa (L.) Gaertn (Combretaceae). Biota Neotropica, 7(3), 163-170.

Montes, M. J. F., Macêdo S. J., \& Koening, M. L. (2002). N: Si: P Atomic Ratio in the Santa Cruz Channel, Itamaracá- PE (Northeast Brazil): a Nyctemeral Variation. Brazilian. Archives of Biology and Technology, 45(2), 115-124.

Nogueira-Melo, G. S., Ryvarden, L., \& Gibertoni, T. B. (2011). First record of Resupinatus poriaeformis (Agaricomycetes) from South America. Mycotaxon, $117,423-427$.

Nogueira-Melo, G. S., Medeiros, P. S., Gomes-Silva, A. C., Ryvarden, L., Sotão, H. M. P., \& Gibertoni, T. B. (2012). Coriolopsis psila comb. nov. (Agaricomycetes) and two new Coriolopsis records for Brazil. Mycotaxon, 120, 223-230.

Núñez, M. \& Ryvarden, L. (2000). East Asian Polypores Vol. 1. Ganodermataceae and Hymenochaetaceae. Synopsis Fungorum, 13, 1-168.

Núñez, M. \& Ryvarden, L. (2001). East Asian Polypores. Vol. 2. Polporaceae sensu. lato. Synopsis Fungorum, 14, 169-522.

Peel, M. C., Finlayson, B. L., \& McMahon, T. A. (2007). Updated world map of the K"oppen-Geiger climate classification. Hydrology and Earth System Sciences, 11, 1633-1644.

Robledo, G. L., Urcelay, C., Domínguez, L., \& Rajchenberg, M. (2006) Taxonomy, ecology and biogeography of polypores (Basidiomycetes) from Argentinian Polylepiswoodlands. Canadian Journal of Botany, 84, 1561-1572.

Robledo, G. L. \& Renison, D. L. (2010). Wood-decaying polypores in the mountains of central Argentina in relation to Polylepis forest structure and altitude. Fungal Ecology, 3, 178-184.

Ryvarden, L. \& Johansen, I. (1980). A preliminary polypore flora of East Africa. Oslo: Fungiflora.

Ryvarden, L. (1991). Genera of polypores, nomenclature and taxonomy. Synopsis Fungorum, 5, 1-363.

Ryvarden, L. (2004). NeotropicalPolypores.Part 1. Synopsis Fungorum, 19, 69-103.

Schaeffer-Novelli, Y., Cintrón-Molero, G. R., Andaime, R., \& Camargo, T. M. (1990). Variability of the Mangrove Ecosystems along the Brazilian coast. Estuaries, 13(2), 204-218.

Schnittler, M. \& Stephenson, S. L. (2000). Myxomycete biodiversity in four different forest types in Costa Rica. Mycologia, 92(4), 626-637.

Silva, M. A. B., Bernini, E., \& Carmo, T. M. S. (2005). Características estruturais de bosques de mangue do estuário do rio São Mateus, ES, Brasil. Acta Botanica Brasilica, 19(3), 465-471.

Sotão, H. M. P., Bononi, V. L. R., \& Figueiredo, T. S. (1991). Basidiomycetes de manguezais da Ilha de Maracá, Amapá, Brasil. Boletim do Museu Paraense Emílio Goeldi, Série Botânica, 7(1), 109-114.

Trierveiler-Pereira, L., Santos P. J. P., \& Baseia, I. G. (2013). Ecological aspects of epigeous gasteromycetes (Agaricomycetes, Basidiomycota) in four remnants of the Brazilian Atlantic Forest. Fungal Ecology, 6, 471-476.

Urcelay, C. \& Robledo, G. (2004). Community structure of polypores (Basidiomycota) in Andean Alder wood in Argentina: Functional groups among wood-decay fungi? Austral Ecology, 29, 471-476.

Webster, J. \& Weber, R. W. S. (2007). Introduction to Fungi. ( $3^{\text {rd }}$ ed.). Cambridge: Cambridge University Press.

Yamashita, S., Hattori, T., Momose, K., Nakagawa, M., Aiba, M., \& Nakashizuka, T. (2008). Effects of Forest Use on Aphyllophoraceous Fungal Community Structurein Sarawak, Malaysia. Biotropica, 40(3), 354-362. 
